\title{
Историко-этнографические материалы как объект междисциплинарного изучения в вузе искусств
}

Ассоциация драматургов северо-запада США (Northwest Playwrights Alliance, WA, USA), и Академия Международного образования в Кобе, Япония (Academy of International Education, Kobe, Japan) выступили с инициативой подготовки и реализации мультиэтнического театрального проекта "Путешествие".

Исходя из опыта координации кросскультурных проектов и преподавания иностранных языков студентам гуманитарных и творческих направлений, необходимо отметить, что навыки и компетенции в педагогической практике нередко формируются в пределах отдельных дисциплин, что вступает в конфликт с сущностью компетентностного подхода и задачами профессионально-ориентированного обучения. Симультанному формированию иноязычных и профрессиональных компетенций способствует согласованность учебных программ, детерминированная дидактическими целями и содержанием.

Теоретическому обоснованию Междисциплинарного подхода, его преимуществам и устранению противоречий в усвоении знаний, комплексному применению теории и практики в профессиональной сфере посвящены работы Е. Г. Гребенщиковой, Т. В. Крепс, Э. М. Мирского, Т. М. Плехановой, С. Ю. Ржеуцкой, М. В. Соловей, Т.А. Старшиновой и других исследователей.

Междисциплинарный подход следует понимать как взаимообусловленную систему интеграции знаний, выраженную в исследованиях и преподавании.

Междисциплинарное взаимодействие рассматривается нами как устойчивая связь между системами дисциплинарного знания в процессе интеграции и диффреренциации наук и коллективных форм работы представителей разных областей знания.

В основе проекта пьеса "Кичи в дебрях памяти о настоящем" ("Kichi in the Woods of Present Memory"), написанная на английском языке художественным руководителем Репертуарного театра Сиэтла Брайаном Уиллисом. Соавтор драматурга - профессиональная актриса, представительница народа Маках - Сесиль Чика.

Координируя очередной кросскультурный проект в России, включая его историко-этнографические, страноведческие и художественные материалы в курс обучения иностранному языку на актёрском факультете Дальневосточного государственного института искусств, мы следуем предложенной нами ранее Методологии формирования партитуры кросскультурного события [1], предпринимаем попытку этносценологического исследования, полагаем целью решение ряда лингводидактических и лингвокультурологических задач:

- на Подготовительном этапе проекта ознакомить студентов с концепцией профессионального проекта "Путешествие" (Tour), биографическими и историческими данными; рассказать о многонациональной труппе, об актёрах и музыкантах, говорящих на английском, японском, и языке народа Маках;

- на Аналитическом этапе в процессе чтения, аудирования, перевода, online коммуникации с участниками проекта рассмотреть некоторые лингвистические и экстралингвистические особенности драматургического текста;

(C) Ахмыловская Л. А., 2021

АХМЫЛОВСКАЯ Лариса Алексеевна, канд. искусствоведения, профессор кафедры общегуманитарных дисциплин Дальневосточного государственного института искусств (2. Владивосток). E-mail: lanaveva@rambler.ru 
- на Постановочном этапе, применяя метод Действенного анализа и профрессиональную терминологию на английском языке, обсудить отдельные фррагменты изучаемого текста и тексты-ассоциации, предлагаемые будущими российскими актёрами в письменных экспликациях и на аудиторных занятиях; учитывая опыт работы над переводом текста пьесы на русский язык и репетищий с русскими профессиональными актёрами [2; 8];

- на Постпостановочном этапе ознакомиться с содержанием рекламной продукции и итогами презентации проекта в США и Японии; принять участие в творческих встречах с создателями спектакля, конференциях и режиссёрских мастер-классах в дни гастролей мультиэтнической труппы в России, планируемых на осень 2022 г. [6-11].

Концепцию представленного нами в статье творческого образовательного проекта, как и идею новой постановки театра, возглавляемого режиссёром Ш. Тьенкен, органично определяет многолетний опыт творческого сотрудничества с театрами и вузами искусств разных стран [3: 5].

В связи с этим творческая биография режиссёра и продюсера Ш. Тьенкен на Подготовительном этапе представляет особый интерес, содержит значительную часть полезной информации, становится одним из учебных текстов наряду с такими материалами, как

- репертуар театра на острове Вашон (Vashon Repertory Theater), отзывы и рецензии;

- информационные тексты, письма, документы о сотрудничестве театров и театральных вузов Сиэтла, Ассоциации драматургов северо-запада США (Northwest Playwrights Alliance) с Приморским краевым драматическим театром молодёжи во Владивостоке в 1992-2006 гг, Приморским краевым Музеем им. В.К. Арсеньева, Оргкомитетом Владивостокской Бьеннале визуальных искусств в 1998, 2000 гг.;

- статьи, посвящённые выставкам приморского художника М. Эйдуса в США 2008-2009 гг.;

- материалы индивидуальной стажировки автора статьи на фракультете драмы Университета штата Вашингон 2008-2009 гг.;

- исторические справки и документы, касающиеся истории народа Маках (Makah Nation), представители которого проживают в северной части полуострова Олимпик, близ острова Ванкувер, в штате Вашингтон, США.

Воспроизводя модели профессионального проекта кросскультурной постановки в образовательном поле, мы включаем в учебный процесс исторические, биографические, театроведческие материалы в форме лексико-грамматических упражнений, тематических глоссариев, тестов для текущего и рубежного контроля, текстов для независимого интертекстуального анализа, разнообразных творческих заданий с учётом специфики творческого вуза, $[12, c .56]$; возможностей медиатехнологий, и с целью формирования профрессиональных компетенций обучаемых [2; 4].

Театрализация как феномен художественного мышления и драматизация как лингвокультурологическая практика в обучении иностранному языку нигде не соединяются так органично, как в вузе искусств, что определяет основные принципы разработки учебных материалов по дисциплине "Иностранный язык".

Приведём примеры упражнений с дословным переводом творческих заданий и представленных отрывков рекламных, исторических, справочных материалов.

Exercise 1. Read and translate the fragments below. Speak on the information obtained. Express your opinion regarding the project. Prove your position. Write down your version of synopsis.

Прочитайте и переведите фррагменты, представленные ниже. Поделитесь информацией. Выразите своё мнение. Аргументируйте свою позицию. Напишите свою версию синопсиса.

On "Tour". O спектакле "Путешествие".Three boys lost at sea wash ashore and become the first Japanese to step foot on North America, and the first to visit London. "Kichi in the Woods of Present Memory" is the story of their courageous but ill-fated attempt to return home to Japan.

Три молодых человека оказались в открытом море, стали первыми японцами, ступившими на североамериканский материк, и первыми, японца- 
ми, посетившими Лондон. "Кичи в дебрях памяти о настоящем" - это рассказ о смелой, но неудавшейся попытке вернуться на родину.

Exercise 2. Give a gist of the following text, as if you were a historian/ producer/TV journalist.

Передайте содержание следующего текста, как если бы Вы были историком/продюсером/тележурналистом.

A. The Tour. Путешествие. This compelling production includes Bunrakuinspired puppetry and tradition Taiko drumming.

Спектакль включает фрагменты, вдохновлённые кукольным театром Бунраку и традиционными барабанами Тайко.

Our tour will take us to the Makah Nation in Washington State, Banbury England and Japan.

Наше путешествие поведет нас к народу Маках, жившему на территории штата Вашингтон, в Бэнбори (Англия) и в Японию.

B. The story. Сюжет. Three young Japanese sailors, including 14-year-old Oto Kichi, drifted over a year before running aground on the Olympic Peninsula in 1834. The sailors were first Japanese to reach what is now Washington State on a wintery day in January 1834.

Три молодых японских моряка, включая 14-летнего Ото Кичи, дрейдровали более года, прежде чем оказались в 1834 г. у Олимпийского полуострова. Они были первыми японцами, достигшими территории нынешнего штата Вашингтон холодным январским днём 1834 г.

C. They were the sole survivors of a crew of 14 that had left Onoura, Japan in October 1832 on a ship bound for Edo (Tokyo) with a cargo of rice and porcelain. The ship was caught in a typhoon, stripped of its rudder, dismasted, and blown out to sea. It drifted across 5,000 miles of ocean before reaching the Northwest coast.

Они были единственными, кто уцелел из четырнадцати моряков, покинувших японский порт Онура с рисом и фрарфором на борту. Судно попало в тайфрун, лишилось руля и мачт, было выброшено в море.

The survivors staggered to shore and promptly encountered a group of Makah seal hunters. Neither the Japanese nor the Makah would have had any idea that the other existed. Japan had been sealed off from the rest of the world for more than 200 years, and the Makah had only limited contact with European fur traders. The Makah took command of the situation and escorted the sailors to the village, where they were put to work gathering seaweed and shellfish.

Те, кто спасся, добрались до берега и вскоре встретились с группой охотников на морских котиков из племени Маках. Ни японцы, ни Маках никогда не слышали о существовании друг друга. Япония была отделена от всего мира более двухсот лет, а Маках имели ограниченные контакты, продавая европейцам меха. Маках сопроводили японских моряков в деревню, где шёл сбор морских водорослей и моллюсков.

D. Agents from the Hudson's Bay Company ransomed them a few months later and took them to the company's regional headquarters at Fort Vancouver. After several months at the fort, the castaways were sent on to London as potential bargaining chips for trade between England and Japan. The negotiation failed and our three sailors were sent to China.

Представители Компании "Бухта Гудзон" выкупили их через несколько месяцев и взяли в центральный офис региональной компании в Форте Ванкувер. Ещё несколько месяцев спустя потерпевшие крушение были отправлены в Лондон, в качестве козырей в сделке между Англией и Японией. Переговоры прошли неудачно, и наши трое моряков были перевезены в Китай.

E. An American merchant named Charles W. King made an effort to repatriate them in 1837 but when King approached Japan with his would-be repatriates, his ship was fired on, twice. He gave up and took the hapless seafarers back to Macao. The youngest sailor, Otokichi eventually became a British citizen and highly successful translator for the British Navy. He settled in Singapore, married and raised three children before dying at the age of 49. This is Oto Kichi's enthralling but little-known story; the 14-year-old shipwreck survivor and his round-the-world quest to return home.

Американский торговец по имени Чарльз У. Кинг в 1837 г. предпринял попытку вернуть их на родину, но когда Кинг вместе с репатриантами был 
уже у берегов Японии, его судно дважды горело. Он отказался от плана и доставил горемычных мореплавателей назад в Макао. Самый юный из моряков, Ото Кичи, впоследствии стал британским подданным и высококвалифицированным переводчиком на Военно-морском флоте. Он поселился в Сингапуре, женился, вырастил троих детей. Умер в сорок девять лет.

Такова захватывающая и почти неизвестная история Ото Кичи; четырнадцатилетнего моряка, потерпевшего кораблекрушение, история его кругосветного путешествия и его попыток вернутся домой.

Exercise 3. Tell about participants of the project, performers \& the crew. Express your attitude, prove your position. Pay your special attention to the functioning of terms of arts. Refer to the worktexts: The Language of Stage, 2019; Tests collection, 2020.

Расскажите об участниках проекта, исполнителях и вспомогательном составе. Выразите своё мнение, аргументируйте своё суждение. Обратите внимание на фрункционирование профессиональной терминологии. См.: Л.А. Ахмыловская, Язык сцены, 2019; Сборник тестов, 2020.

A. The artistic team. Постановочная группа. Director-Charlotte Tiencken, Vashon Repertory Theatre, Producing Artistic Director. Режиссёp Шарлотт Тьенкен, продюсер и художественный руководитель репертуарного театра острова Вашон.

Writers: Bryan Willis, Artistic Director, Northwest Playwrights Alliance, Seattle Repertory Theatre, Cecil Cheeka, Professional Actor and life-long member of the Makah Nation.

Авторы текста: Брайан Уиллис, глава Ассоциации драматургов северо-запада и художественный руководитель Репертуарного театра Сиэтла, Сесиль Чика, профессиональная актриса, представительница народа Маках.

Chikako Kaneto \& Takuya Matsumoto, Managing Directors, Academy of International Education (Kobe). Чикако Кането и Такуа Матцумото, представители администрации Международной Академии образования (Кобе). Yuto Yuwata, Taiko Drum composer. Юто Ювата композитор, автор музыки для барабана Тайко.

Exercise 4. Speak on the Northwest Playwrights Alliance. Use Direct and Indirect speech. Write a letter to your foreign colleague playwright/director/actor. Be ethical and positive. See the patterns: L.A. Akhmylovskaia, Written English Speech in Cross-Cultural Communication, 2019.

Расскажите об Ассоциации драматургов северо-запада. Используйте прямую и косвенную речь. Напишите письмо зарубежному коллеге драматургу/режиссёру/актёру. Будьте этичны и позитивны. См.: Л.А. Ахмыловская, Письменная английская речь в кросскультурной коммуникации, 2019.

On the Northwest Playwrights Alliance. NPA is based at Seattle Repertory Theatre and has produced hundreds of plays in the last 18 years. We also publish short works and have sponsored ten international tours with performances in New York City, England and Japan.

Об Ассоциации драматургов. За последние восемнадцать лет Ассоциация драматургов северо-запада и Репертуарный театр Сиэтла представили публике сотни пьес. Миссия ассоциации: публикация пьес и участие в подготовке международных гастролей в Нью-Йорке, Великобритании и Японии.

Предполагаемое время реализации профессионального мультиэтнического проекта исчисляется двенадцатью-восемнадцатью месяцами. Воспроизводя его основные этапы (Подготовительный, Аналитический, Постановочный, Постпостановочный) в образовательном творческом проекте, мы лишь очерчиваем план, которому следуем, используя учебное аудиторное и внеаудиторное время для формирования и развития иноязычных компетенций студентов вуза искусств.

Следуя принципам контекстного обучения, имея целью развитие иноязычной компетенции актёра, сближая образовательное пространство с профессиональным, мы на практике убеждаемся в универсальности Методологии формирования переводческой партитуры кросскультурного события и её әфрективности.

Включённое наблюдение профессионального мультиэтнического проекта, диалог с его участниками трансформируют процесс обучения иностранному языку в опыт международного сотрудничества. 
Участие в подобных проектах позволяет будущим актёрам:

- изучать аутентичные художественные, историко-этнографические, этносценологические, этнопсихологические, культурологические, театроведческие материалы на английском языке;

- получать доступ к регионоведческим коллекциям, архивным документам, статьям и комментариям действующих здесь и сейчас практиков театра разных стран;

- знакомиться с внутренней жизнью и профрессиями театров мира, театральным администрированием, основами продюсерской работы, разнообразными видами фестивальной деятельности, новыми формами проведения мастер-классов и междисциплинарных творческих лабораторий.

\section{Литература}

1. Ахмыловская, Л.А., Формирование переводческой партитуры пьесы в кросскультурном проекте. - Владивосток: ДВГТУ, 2010234 с.

2. Астафьева Т.В. Интеграционно-дистанционная форма постановки современных театрализованных представлений и праздников как результат развития медиатехнологий / Т.В. Астафьева, В.Ф. Кудашов // Вестник Кемеровского государственного университета культуры и искусств. 2020. № 52. С. 56-62.

3. Марути Ая. Основные проблемы воспитания актера в японской театральной школе: автореф. дис. канд. иск. М.: 2010. 26 с.

4. Плотникова К.П. Современные проблемы театрального образования // Санкт-Петербургский образовательный вестник. 2017. № 5 (9). С. 27-29.

5. Пономарьова М. Процесс воспитания актёра в странах Западной Европы (Франция, Англия) / М. Пономарьова // Проблеми взаемодії мистецтва, педагогіки та теорії і практики освіти. 2012. Вип. 37. С. 269-280. URL: http://nbuv.gov.ua/UJRN/ Pvmp_2012_37_25. (дата обращения: 09.08.2021).

6. Шалимова Л.А. Эстетика грима в цветовой компоненте театрального искусства // Мир науки, культуры, образования. 2013. № 6 (43). C. 477-479. URL:https:// cyberleninka.ru/article/n/estetika-grima-v-tsvetovoy-komponente-teatralnogo-iskusstva (дата обращения: 08.08.2021).

7. Strasberg Lee. A dream of Passion. The development of method. Little, Brown and Company, Boston, 1987. $201 \mathrm{p}$.

8. Carnicke Sharon M. Stanislavsky in focus. Russian Theatre Archive; v.17, London: Hardwood Academic Publishers, 2003. 236 p.

9. Conable B., Conable W. How to learn the Alexander technique. Columbus, Ohio, Andover Press, 1995. 154 p.

10. Sidoní López Pérez. The unstable development of contemporary Native American theatre. 2018 URL: https://www.dpublication.com/wp-content/uploads/2018/12/ICSHE1-P-108.pdf (дата обращения: 07.09.2021).

11. Skinner Edith. Speak with distinction. The Classic Skinner Method to speech on the stage. NY: Applause. Theatre Book Publishers, 1990. 406 p.

12. Thurow Susanne. Multi-Modal Aesthetics - Rendering Complexity through Integrated Performative Storytelling. Abstract Book, 5th Annual International Symposium on Culture and Civilization 8-11 June 2020, Athens, Greece THE ATHENS INSTITUTE FOR EDUCATION AND RESEARCH. URL: https://www.atiner.gr/abstracts/2020ABSTCUL.pdf (дата обращения: 08.09.2021).

\section{Транслитерация по ГОСТ 7.79-2000 система Б}

1. Akhmylovskaya, L.A., Formirovanie perevodcheskoj partitury p'esy v krosskul'turnom proekte. - Vladivostok: DVGTU, 2010 - $234 \mathrm{~s}$.

2. Astaf'eva T.V. Integratsionno-distantsionnaya forma postanovki sovremennykh teatralizovannykh predstavlenij i prazdnikov kak rezul'tat razvitiya mediatekhnologij / T.V. Astaf'eva, V.F. Kudashov // Vestnik Kemerovskogo gosudarstvennogo universiteta kul'tury i iskusstv. - 2020. - № 52. - S. 56-62.

3. Maruti Aya. Osnovnye problemy vospitaniya aktera v yaponskoj teatral'noj shkole: avtoref. dis. kand. isk. Moskva, 2010.26 s

4. Plotnikova K.P. Sovremennye problemy teatral'nogo obrazovaniya // Sankt-Peterburgskij obrazovatel'nyj vestnik. 2017. № 5 (9). C. 27 - 29 .

5. Ponomar'ova M. Protsess vospitaniya aktyora v stranakh Zapadnoj Evropy (Frantsiya, Angliya) / M. Ponomar'ova // Problemi vzaemodiï mistetstva, pedagogiki ta teoriï i praktiki osviti. - 2012. - Vip. 37. - S. 269-280. URL: http://nbuv.gov.ua/UJRN/ Pvmp_2012_37_25. (data obrashheniya: 09.08.2021). 
6. SHalimova L.A. EHstetika grima v tsvetovoj komponente teatral'nogo iskusstva // Mir nauki, kul'tury, obrazovaniya. - 2013. - № 6 (43). - S. 477-479. URL:https://cyberleninka.ru/article/n/estetika-grima-v-tsvetovoy-komponente-teatralnogo-iskusstva (data obrashheniya: 08.08.2021).

7. Strasberg Lee. A dream of Passion. The development of method. Little, Brown and Company, Boston, 1987. - $201 \mathrm{p}$.

8. Carnicke Sharon M. Stanislavsky in focus. Russian Theatre Archive; v.17, London: Hardwood Academic Publishers, 2003. - 236 p.

9. Conable B., Conable W. How to learn the Alexander technique. - Columbus, Ohio, Andover Press, 1995. - 154 p.

10. Sidoní López Pérez. The unstable development of contemporary Native American theatre. 2018 URL: https://www.dpublication.com/wp-content/uploads/2018/12/ICSHE1-P-108.pdf (data obrashheniya: 07.09.2021).

11. Skinner Edith. Speak with distinction. The Classic Skinner Method to speech on the stage. - NY: Applause. Theatre Book Publishers, 1990. - 406 r.

12. Thurow Susanne. Multi-Modal Aesthetics - Rendering Complexity through Integrated Performative Storytelling. Abstract Book, 5th Annual International Symposium on Culture and Civilization 8-11 June 2020, Athens, Greece THE ATHENS INSTITUTE FOR EDUCATION AND RESEARCH. URL: https://www.atiner.gr/abstracts/2020ABST-CUL. pdf (data obrashheniya: 08.09.2021).

Ахмыловская Л. А. Историко-этнографические материалы как объект междисциплинарного изучения в вузе искусств.

В статье представлен опыт включения материалов историко-этнографического исследования в кросскультурный театральный проект. Процесс подготовки проекта становится объектом анализа в условиях обучения иностранному языку на актёрском факультете. Изучение постановки профессионального спектакля мультиэтнической труппы методом включённого наблюдения дополняет опыты международных фестивалей, мастер-классов, междисциплинарных лабораторий, открывает новые возможности развития проектного метода в контекстном обучении.

Ключевые слова: мультиэтнический театральный проект, лингвострановедческий подход, контекстное обучение актёра, включённое наблюдение, независимый интертекстуальный анализ, этносиенологическое исследование

Akhmylovskaya L. A. History and Ethnography materials as the object of interdisciplinary studies at the Higher School of Arts.

The article presents the experience of history and ethnology studies within crosscultural project. The project realization becomes the object of analysis under the conditions of English teaching at the Higher School of Drama. The participant observation of the professional production and multinational tour promotion contributes to the experience of the International festivals, master-classes, interdisciplinary laboratories; outlines new opportunities of project method developing for professional training of an actor.

Key words: multiethnic theatre making project, linguistic and cultural approach, context training of an actor, participant observation, independent intertextual analysis, ethnoscenological research

Для цитирования: Ахмыловская Л. А. Историко-этнографические материалы как объект междисциплинарного изучения в вузе искусств // Ойкумена. Регионоведческие исследования. 2021. № 4. C. 146-151. DOI: 10.24866/1998-6785/2021-4/146-151

For citation: Akhmylovskaya L. A. History and Ethnography materials as the object of interdisciplinary studies at the Higher School of Arts // Ojkumena. Regional researches. 2020. № 1. P. 146-151. DOI: 10.24866/1998-6785/2021-4/146-151 